\title{
The Increasing Global Market For Health Care: The Effect Of Emerging Technologies On Global Outsourcing \& Offshoring Of Health Care Services
}

J. Jay Mackie, Shippensburg University, USA

Monica E. Oss, OPEN MINDS, Gettysburg PA, USA

\begin{abstract}
The use of outsourcing as a business management tool has a long history in the delivery of health and human services in the United States. But, the current price-pressured, highly-competitive U.S. health and human service market is also experiencing new competitive developments due to the introduction of new technologies and further use of lower-cost labor markets outside of the United States, commonly referred to as offshoring. This paper will explore the evolution of outsourcing and offshoring in health and human services and provide a model to analyze the technological factors that will likely contribute to a global transformation of the health and human services. Traditional thinking is that offshoring is usually limited to highly-repetitive, lowskill service tasks such as data entry and call center management. But, new research on the concept of offshoring posits that services that are labor intensive, information-based, codifiable, and/or highly transparent are candidates for technology-enabled outsourcing. A broader shift in labor models, from local to global, is likely to occur. Since these four characteristics apply to many of the professional functions in the health and human service field, it is imperative that health care executives understand the potential risks and opportunities of these emerging technologies. In particular, the authors will review the likely health service functions that will be subject to worker/labor competition through global outsourcing and suggest possible strategies for organizations in the field to address these new competitive threats.
\end{abstract}

Keywords: Health care, outsourcing, offshoring, health services, technology.

\section{INTRODUCTION}

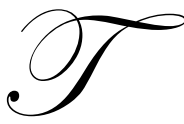

he use of outsourcing as a business management tool has a long history in the delivery of health and human services in the United States. But, the current price-pressured, competitive U.S. health and human service market has recently seen two new competitive developments due to the further use of lower-cost labor markets outside of the United States. The first development, with the smaller current impact on organizational strategy, is the growing medical tourism phenomenon (Forgione and Smith, 2007, Wanless, 2008). The second development is the use of technology to enable the outsourcing of additional components of the health care delivery system - and outsourcing using labor from outside the United States. This global or offshore outsourcing is commonly referred to as offshoring.

Much has been written - particularly in the popular press -- about medical tourism and the allure of foreign destinations for specialty health care services Executives of health and human service provider organizations have been slow to recognize the looming impact of technology-enabled outsourcing on market competitiveness. Traditional thinking is that this type of offshoring is limited to highly-repetitive, low-skill service tasks such as data entry and call center management. But, new research on the concept of offshoring posits that services that are labor 
intensive, information-based, codifiable, and/or highly transparent are candidates for technology-enabled outsourcing and, therefore, subject to shifting the labor compensation models from local to global. Those four characteristics apply to many of the professional functions in the health and human service field.

An additional complication for health and human service organizations is that the strategic effects of offshore outsourcing will not wait to be felt until there is consumer acceptance of 'global' health care professionals or established relationships with heath care institutions in other countries. The intersection of higher-speed, lowercost technologies, a large supply of professional labor available globally with markedly different compensation rates, and the shift in the U.S. to more consumer participation in the financing and selection of health care services (OPEN MINDS, 2008) will move the health and human service market rapidly toward the use of offshoring. However, the competitive effects will be noted in the field before this market shift fully occurs. Because U.S. health and human service organizations have been operating in competitive spheres that have been defined by consumer travel distances and local labor markets, technology-enabled outsourcing will first have its effect in the U.S. by disrupting local markets with 'out of area' (but within the U.S.) labor. This intra-country effect will recalibrate the competitive equation in many local markets and likely smooth the adoption of inter-country or offshoring of these services.

The implications of these developments on the operational and marketing strategies of organizations operating in the U.S. health and human service market are many. From the strategic perspective, outsourcing (whether intra-country or offshore) will redefine 'competition' and modify standards for the cost of the labor component in many services. Executive teams of provider organizations will need new models for demonstrating the value proposition of services - in terms of payer and consumer perceptions of quality and service relative to service cost. In addition, at the operational level, questions of risk management, integration of technology in service delivery models, and remote management are just a few of the new issues to be considered. This paper examines the factors that are likely to contribute to a global transformation of the health and human services. In particular, the authors will review the likely health service functions that will be subject to worker/labor competition through global outsourcing and possible strategies for organizations in the field to address these new competitive threats.

\section{THE EVOLUTION OF OUTSOURCING IN U.S. HEALTH AND HUMAN SERVICES}

Outsourcing in the health care market can be viewed as an evolutionary process that began with the basic goal of finding ways to reduce costs while maintaining a high quality of patient care. In its most general form, outsourcing involves the transfer of the management and/or day-to-day execution of an entire business function to an external service provider (Overby, 2007). The client organization and the service supplier enter into a contractual agreement that defines the transferred services. Under the agreement the supplier acquires the means of production in the form of a transfer of people, assets, and other resources from the client. The client agrees to procure the services from the supplier for the term of the contract.

Traditionally, offshore outsourcing or offshoring has been defined by the transfer of an organizational function to another country, regardless of whether the work is outsourced to a third party or stays within the same corporation (Norwood, 2006, Babu, 2005). However, the increasing globalization of commerce and the effects of technology have changed the conceptualization of offshoring. Blinder (2005) has redefined offshoring for the business community to refer specifically to outsourcing work to firms or subsidiaries employing labor outside the home country. And, for the purposes of this analysis of the evolution and effect of offshoring on the health and human service sector, the Blinder definition will be used.

The health and human service field has long operated under the ubiquitous premise that "all health care is local". But, throughout the past decades there have been many exceptions to this. U.S. citizens have sought cancer treatment with laetrile in Mexico and unapproved cosmetic surgery procedures in Switzerland for decades. The concept of "centers of excellence" was introduced by the U.S. Federal government in 1991 (Hamilton and Fisher, 2006). These examples involved the consumer physically moving to another venue to seek specialized, better quality, or better value from a service provider. Another exception to the 'local' nature of health care has been the use of outsourcing to supply specialized staff or functions at a health care facility. The most typical examples 
involve the outsourcing of non-core services - everything from the management of food service functions to the provision of maintenance services - to other organizations. However, in recent years, responding to local shortages of particular types of professionals, many health and human service organizations have contracted with organizations that bring in these professional staff from countries outside of the U.S. - in particular nurses and physical therapists.

If there has been historical use of outsourcing this service sector, why is outsourcing likely to become a more critical strategic issue for health and human service organizations? The underlying environmental change is technological - the declining costs and increasing functionality of telecommunications technology. Essentially, technology is eliminating physical presence as an issue - eliminating the need for consumers to travel to take advantage of lower-cost labor markets and eliminating the need for professionals in lower-cost markets to travel to the consumer to provide service.

In addition to this underlying change in the technologies supporting the delivery of health and human services, three other factors are speeding the application of these technologies in the U.S. market:

- The pressure of U.S. public and private payers to decrease the cost of health and human services for the U.S. population

- $\quad$ The growing involvement - both clinically and financially -- of consumers in decisions about their services and service providers (Oss, 2007)

- $\quad$ The widening gap between professional labor costs in the U.S. market and other world markets

There are four common market applications of outsourcing in the U.S. health and human service markets. Location-specific outsourcing has two types -- on-site functional outsourcing and the off-site "medical tourism" model of outsourcing. Technology-enabled outsourcing also has two models - the off-site outsourcing of non-core services and the ability to use technology to incorporate non-U.S. health care professionals into the delivery of core services. The four common market models of outsourcing in the U.S. health and human service markets are summarized in Table 1.

As previously stated, location-specific outsourcing first enabled health and human service organizations to help contain costs by contracting out the delivery of basic, non-core administrative and support services to specialty vendor organizations. In some local markets, organizations also contracted with specialty organizations to recruit and import specialty service professionals from countries outside the U.S. These first efforts at outsourcing were basically on-site and functional and typically involved substituting current employed staff with contractors employed by an outside firm. This allowed these organizations to reduce the unit costs of services and improve their marketability and profitability without affecting the quality of their main, core services.

A second type of outsourcing, medical tourism, involves the movement of consumers of service, rather than staff. This medical tourism has two variations. The first involved the 'brand' extension of U.S. health care providers both in the U.S. and abroad. In the face of increasing competition in local markets, cost pressures, and the mobility of consumers, many organizations established new service locations that in other geographic regions that use local health care professionals and allowed market access to new groups of consumers without requiring the consumer to travel. The Mayo Clinic facilities operating in Arizona, Florida or Dubai serves as an example of this market phenomenon. The second variation is the promotion of health service organizations outside the U.S. to U.S. consumers - with the assumption that the consumer would travel to a different locale to take advantage of lowercost labor rates.

Technology-enabled outsourcing refers to the developments brought on by advances in technology that allowed remote data collection and secure transmission of sensitive data. Health care organizations saw this as an additional method of reducing their operating costs and remaining competitive. Initially, this outsourcing was concentrated in the non-core services and technology now made it possible to outsource these services on a global scale. The earliest examples were aimed at controlling administrative costs involving their basic business processes and information systems. Controlling administrative costs allowed health care organizations to automate many of the 
previously, manual operations, such as claims processing, eligibility verification, medical records, billing and financial management and reporting functions and customer call centers. And as the costs and complexity of operating and maintaining organizations' information systems grew, the outsourcing of information technology (IT) expanded and allowed these organizations to continue to focus on their core competencies.

More recent technological advances have further driven this technology-enabled outsourcing to include many of the health care organizations core services. With the ability to outsource services globally, there was the expanded ability to provide services from locations that offered significant cost savings while maintaining the overall quality of service. While this area has begun slowly due to concerns about quality and customer acceptance, it still presents a very promising area of strategic importance to health care providers trying to remain competitive and maintain and/or expand their markets.

The key market factor for health and human service organizations when considering the impact of technology-enabled outsourcing is that it eliminates the factor of location in taking advantage of lower labor costs. Neither the staff member nor the consumer needs to travel to experience the benefits of the lower-cost labor market. And with technology-enabled outsourcing, the location of the remote service delivery - whether within the U.S., in North America, or elsewhere is irrelevant

\begin{tabular}{|c|c|c|c|}
\hline \multicolumn{4}{|c|}{ Table 1} \\
\hline \multicolumn{4}{|c|}{ Outsourcing in the U.S. Health \& Human Service Market } \\
\hline \multicolumn{2}{|c|}{ Location-Specific Outsourcing Model } & \multicolumn{2}{|c|}{ Technology-Enabled Outsourcing Model } \\
\hline $\begin{array}{l}\text { On-Site Functional } \\
\text { Outsourcing }\end{array}$ & $\begin{array}{l}\text { "Medical Tourism" As } \\
\text { Outsourcing }\end{array}$ & $\begin{array}{l}\text { Technology-Enabled } \\
\text { Outsourcing of Non-Core } \\
\text { Services }\end{array}$ & $\begin{array}{c}\text { Technology-Enabled } \\
\text { Outsourcing of Core Services }\end{array}$ \\
\hline $\begin{array}{l}\text { Defining characteristic in } \\
\text { evolution: Staff physically } \\
\text { present at service location } \\
\text { but employed by another } \\
\text { organization. }\end{array}$ & $\begin{array}{l}\text { Defining characteristic in } \\
\text { evolution: Consumer } \\
\text { physically present at 'global' } \\
\text { service location; extension of } \\
\text { 'brand' to another market or } \\
\text { seeking out lower cost } \\
\text { provider }\end{array}$ & $\begin{array}{l}\text { Defining characteristic: Staff } \\
\text { connected to organization by } \\
\text { technology but behind the } \\
\text { "line of visibility" with } \\
\text { payers/consumers (i.e. non- } \\
\text { core services) }\end{array}$ & $\begin{array}{l}\text { Defining characteristic: Staff } \\
\text { connected to the organization } \\
\text { and the payer/consumer by } \\
\text { technology; and responsible for } \\
\text { provision of core services in the } \\
\text { health and human service } \\
\text { system. }\end{array}$ \\
\hline $\begin{array}{l}\text { Market implication: } \\
\text { Allows the reduction of } \\
\text { unit costs of services or } \\
\text { improvement of market } \\
\text { positioning by decreasing } \\
\text { the cost or increasing the } \\
\text { value of services delivered } \\
\text { by specialty organization } \\
\text { offering outsourced service }\end{array}$ & $\begin{array}{l}\text { Market implication: Allows } \\
\text { the consumer to take } \\
\text { advantage of lower cost of } \\
\text { service if they are willing to } \\
\text { travel to location with lower } \\
\text { labor market rates and accept } \\
\text { the possible risks associated } \\
\text { with such locations. }\end{array}$ & $\begin{array}{l}\text { Market implication: Allows } \\
\text { the further reduction of unit } \\
\text { costs of services by taking } \\
\text { advantage of lower wage rate } \\
\text { markets (in the U.S. or } \\
\text { abroad) for the delivery of } \\
\text { non-core services through } \\
\text { technology-enabled } \\
\text { platforms. }\end{array}$ & $\begin{array}{l}\text { Market implication: } \\
\text { Allows the further reduction of } \\
\text { unit costs of services by taking } \\
\text { advantage of lower wage rate } \\
\text { markets (in the U.S. and } \\
\text { abroad) for the delivery of core } \\
\text { health care services through } \\
\text { technology-enabled platforms }\end{array}$ \\
\hline Examples & Examples & Examples & Examples \\
\hline $\begin{array}{l}\text { International nursing and } \\
\text { physical therapist staffing } \\
\text { services -- Nursing } \\
\text { Staffing Agency, Maxim } \\
\text { Healthcare Services, }\end{array}$ & $\begin{array}{l}\text { Johns Hopkins Healthcare } \\
\text { System delivery system } \\
\text { projects in Portugal, } \\
\text { Lebanon, Dubai, Singapore, } \\
\text { Tokyo, Chile, Panama, } \\
\text { Trinidad, and Mexico }\end{array}$ & $\begin{array}{l}\text { Remote customer service call } \\
\text { centers for health care } \\
\text { organizations - IntellCare } \\
\text { eligibility call center for } \\
\text { health plans }\end{array}$ & $\begin{array}{l}\text { Specialist consultations via on- } \\
\text { line technology -- IntellCare } \\
\text { 'nurse line', Pathologists } \\
\text { Overseas, Global Medical } \\
\text { Systems }\end{array}$ \\
\hline $\begin{array}{l}\text { Contract management of } \\
\text { billing and technology } \\
\text { departments of health and } \\
\text { human service } \\
\text { organizations - The SSI } \\
\text { Group, Accuclaim Medical } \\
\text { Billing Outsourcing } \\
\text { Services }\end{array}$ & $\begin{array}{l}\text { "Medical tourism" consumer } \\
\text { facilitation services -- } \\
\text { Medretreat, Meditravels, } \\
\text { MedTrava, MedicalNomad, } \\
\text { Healthcare Beyond } \\
\text { Boundaries, PlanetHospital }\end{array}$ & $\begin{array}{l}\text { Remote hospital billing } \\
\text { management (not on-site) -- } \\
\text { Hospital Billing Services } \\
\text { (India), Payer Connection, } \\
\text { LLC, }\end{array}$ & $\begin{array}{l}\text { Mental health services on-line - } \\
\text { eGetGoing, LiveAdvice.com }\end{array}$ \\
\hline
\end{tabular}




\section{CHARACTERISTICS OF SERVICES VULNERABLE TO OFFSHORE OUTSOURCING}

The question for executives of health and human service firms is not whether offshoring will occur, but which functions in the health and human service delivery system will be subject to the economic pressures of offshoring - and at what speed in the market that phenomenon will occur. While Blinder (2004) posited that health care would be immune to offshoring "for a very long time" with the exception of selected functionality, he did concede that "with a little imagination, we can envision. . medical procedures being performed by doctors who are thousands of miles away. .."

An analysis of the characteristics that make specific jobs vulnerable to offshoring support a different view of the speed of application of offshoring in health and human services. Rapid development of technology applications specific to health care - in an environment with growing pressure from payers and consumers to control health care costs - could lead to more rapid movement of portions of the health and human service labor market to offshore locations. According to Garner (2004), there are four characteristics of service sector jobs that have been identified as making them vulnerable to offshoring:

$\begin{array}{ll}- & \text { Labor intensive } \\ - & \text { Information-based } \\ - & \text { Codifiable } \\ - & \text { High transparency of information exchange between consumer and service provider }\end{array}$

Labor intensity is the first and most important factor. For those service sectors where cost of labor is a major factor in service costs, the comparative advantage of moving services to less costly labor markets is a key to competitiveness. Information-based suggests that as technology becomes more advanced in transmitting and manipulating information, the ability to offshore jobs that collect and use information in health care and the feasibility of providing services remotely will increase. Jobs that are driven by a routine set of rules or instructions, or codifiability, require less training and experience and are also more likely to be offshored because of the ability to use technology or lower cost labor markets to guide and facilitate these decision making processes. And, finally, in those situations where there is a high degree of transparency in information sharing between consumer and service provider, offshoring of the function is more likely to occur since there is no requirement for specific face-to-face interaction.

The question for the evolution of strategy in the field is the speed of adoption of offshoring and the specific functions that can be delivered via technology. Table 2 provides a listing of some of the core health and human service system functions that may be subject to offshoring.

It is easy for analysts to point to the labor intensity of health care services, with over $80 \%$ of total budgets in health and human service organizations related to the costs of labor. However, the growing use of clinical treatment algorithms, evidence-practice protocols, interoperable electronic health records, on-line consumer health records, and video health functionality are contributing to the growing ability to offshore significant professional functions in the health and human service system - both administrative functions and core clinical service functions. It is also critical for health and human service organizations to recognize the potential effects of global medical tourism on their current operations. As healthcare plans move toward a more consumer based approach and global medical tourism gains more interest and acceptance by many American consumers, the potential organizational effects in this area should be analyzed. As the rate of evolution of these and other practices accelerate, the use of offshoring in the health and human service sector, along with the need for executive teams to address the concomitant strategic and operational issues related to offshoring, will be critical to success. 


\begin{tabular}{|c|c|c|c|c|}
\hline \multicolumn{5}{|c|}{ Table 2} \\
\hline \multicolumn{5}{|c|}{ Offshoring Characteristics Of Core Health \& Human Service Functions } \\
\hline $\begin{array}{c}\text { Health \& Human Service Delivery } \\
\text { System Function }\end{array}$ & $\begin{array}{l}\text { Labor } \\
\text { Intensive }\end{array}$ & $\begin{array}{l}\text { Information } \\
\text {-Based }\end{array}$ & Codifiable & $\begin{array}{c}\text { High Transparency Of } \\
\text { Information Exchange With } \\
\text { Technology }\end{array}$ \\
\hline $\begin{array}{l}\text { Telephone call centers, nurse lines, } \\
\text { suicide hotlines, etc. }\end{array}$ & $\mathrm{X}$ & $\mathrm{X}$ & $\mathrm{X}$ & $\mathrm{X}$ \\
\hline $\begin{array}{l}\text { Electronic billing and customer service } \\
\text { functions }\end{array}$ & $\mathrm{X}$ & $\mathrm{X}$ & $\mathrm{X}$ & $\mathrm{X}$ \\
\hline Medical transcription & $\mathrm{X}$ & $\mathrm{X}$ & $\mathrm{X}$ & $\mathrm{X}$ \\
\hline Consumer education & $\mathrm{X}$ & $\mathrm{X}$ & $\mathrm{X}$ & $\mathrm{X}$ \\
\hline $\begin{array}{l}\text { Monitoring of evidence-practice } \\
\text { implementation }\end{array}$ & $\mathrm{X}$ & $\mathrm{X}$ & $\mathrm{X}$ & $\mathrm{X}$ \\
\hline Psychological testing & $\mathrm{X}$ & $\mathrm{X}$ & $\mathrm{X}$ & $\mathrm{X}$ \\
\hline Laboratory test analysis & $\mathrm{X}$ & $\mathrm{X}$ & $\mathrm{X}$ & $\mathrm{X}$ \\
\hline Mental health therapy & $\mathrm{X}$ & $\mathrm{X}$ & $\mathrm{X}$ & $\mathrm{X}$ \\
\hline Remote prescribing of medication & $\mathrm{X}$ & $\mathrm{X}$ & $\mathrm{X}$ & $\mathrm{X}$ \\
\hline $\begin{array}{l}\text { Remote monitoring of chronic (not } \\
\text { acute) conditions }\end{array}$ & $\mathrm{X}$ & $\mathrm{X}$ & $\mathrm{O}$ & $X$ \\
\hline Clinical/professional training & $\mathrm{X}$ & $\mathrm{X}$ & $\mathrm{X}$ & $\mathrm{O}$ \\
\hline Consumer self-care & $\mathrm{X}$ & $\mathrm{X}$ & $\mathrm{X}$ & N/A \\
\hline $\begin{array}{l}\text { Symptom monitoring and algorithm- } \\
\text { supported diagnostic evaluations }\end{array}$ & $\mathrm{X}$ & $\mathrm{X}$ & $\mathrm{X}$ & N/A \\
\hline Clinical decision support tools & $\mathrm{X}$ & $\mathrm{X}$ & $\mathrm{X}$ & N/A \\
\hline Chronic disease management & $\mathrm{X}$ & $\mathrm{X}$ & $\mathrm{O}$ & $\mathrm{O}$ \\
\hline $\begin{array}{l}\text { Specialist consultation (radiology, } \\
\text { pathology, second opinions) }\end{array}$ & $\mathrm{X}$ & $\mathrm{O}$ & $\mathrm{O}$ & $X$ \\
\hline Surgery and other invasive procedures & $\mathrm{X}$ & $\mathrm{O}$ & $\mathrm{O}$ & $\mathrm{O}$ \\
\hline
\end{tabular}

\section{CONCLUSIONS: STRATEGIC ISSUES FOR RESPONDING TO OFFSHORING IN THE HEALTH AND HUMAN SERVICE FIELD}

As we have explored the evolution of outsourcing and offshoring in health and human services, it is apparent that executives of organizations in the field would be well advised to prepare for the possible changes that will be affecting their field. The rate of change is hard to estimate, but it is clear that such change will come and organizations need to be prepared to address key strategic issues in order to effectively respond to these changes.

The effects of offshoring are not necessarily negative for organizations in the U.S. health and human service field. Many organizations currently outsource key functions - and have done so to reduce costs and remain competitive. Offshoring holds similar potential rewards, but also has a significant level of risk. Health and human service organizations must recognize the potential for change; understand the effects and speed of change for offshoring of specific functions; assess the risks to their organizations, and prepare strategically for these future effects.

Generally, organizations will likely have one of three distinct strategies - based on low, moderate, and high level of market effect -- in response to offshoring. For market scenarios where offshoring poses a low risk to the organization's competitiveness, a defensive strategy is likely the best option. In the defensive low-risk strategy, the organization would downplay the benefits of offshoring to customers and take an active interest in informing potential users of the downside risks. They may continue to make use of outsourcing opportunities that helped them reduce costs, but they would also benefit from promoting some of the risks and negative associations with offshoring. Many reports blame offshoring for some of the negative economic results, moving jobs overseas, loss of good paying jobs, etc., and this can be used as a careful strategy to reduce the interest in offshoring or medical tourism expressed by current customers. Specific to medical tourism, health care providers could promote the 
quality of there own services, while advancing some of the potential negatives- fear of travel to offshore locations, increased exposure to disease, and potential post-operation and health coverage problems.

A second strategy would be acceptance that offshoring will have a moderate impact on their organization and consider the options to plan for this new environment. The strategy would require an assessment of how to change their market positioning to take advantage of offshoring and maintain a reasonable level of investment to keep up with their competition for expanded offshoring. The third strategy is a more aggressive approach based on a determination that offshoring will have significant current and long-term effect on their competitive environment. It would require a more detailed understanding of these longer term effects and a more aggressive strategic investment in areas needed to remain competitive.

For those organizations that determined that they will face moderate to high levels of change in their competitive positioning due to offshoring, they would need to assess how they can make use of offshoring opportunities and actively seek to invest and develop these areas. These organizations need to prioritize their processes, keeping their core processes in-house and use offshoring for their commodity, non-core processes in order in increase customer value proposition (Aron and Singh, 2005). The extent of these changes would depend on their risk assessment and might entail any of a number of potential opportunities. Some of the potential strategies include:

1. Eliminate non-competitive services that cannot be reformulated in the new environment

2. Deploy strategies - including offshoring and other global service partnerships - to reformulate current services and maintain parity in terms of customer value proposition

3. Analyze consumer demographics to determine the specific consumer subpopulations that are 'best fit' for current service positioning and shift marketing focus to those subpopulations

Trimming organizational service offerings is one response to major market shifts caused by offshoring. Analysis of organizational service portfolios will be particularly critical as economies of scale, consumer/professional service interactions, and value propositions are shifting among competitors in a market. The ability to recognize early that certain services are no longer meeting their margin requirements and cannot be repositioned or reformulated in the market is critical to save capital for those activities for other services. Reformulation of service offerings in the face of competitive developments is a second option. Reformulation can take a variety of forms, including participating in similar offshoring activities to gain equivalent economies of scale. The reformulation can also look at competitive technologies and service approaches to differentiate services in the market. Typical examples of service reformulation is the 'repurposing' of institutions to serve different consumer populations and the development of specialty consultation services for medical specialties where routine diagnostic work is threatened by on-line global competition.

A final strategy for markets with significant offshoring impact is to better define consumer subpopulations - with a focus on those that will not be interested (make their service selection decisions) based on the market differentiation introduced by offshoring. A financial analysis to provide clear understanding of the margins possible serving a smaller number of consumers is essential. And to make this strategy success, better cultivation of consumer relationships within the demographic subpopulation is key.

As Wanless (2008) suggested, each of the potential strategies will require some very important and careful planning. The tools for these strategic analyses, as well as the best practice models for addressing the management issues inherent in an environment with technology-enabled offshoring - financial risk management, service process reengineering to incorporate new technologies, and remote professional staff management, will be the subject of future research.

\section{AUTHOR INFORMATION}

J. Jay Mackie, Ph.D., Associate Professor, Department of Accounting and Management Information Systems, Shippensburg University. His background includes over twenty five years of experience in both academic and 
business settings. Dr. Mackie has numerous publications dealing with health care, cost management and information systems and his current research interests involve information technology and strategic cost management in the health care industry.

Monica E. Oss, is the founder and chief executive officer of OPEN MINDS, a national market research and management consulting firm specializing in the health and human service field. She leads the OPEN MINDS consulting practice and serves as executive editor of its information services divisions. She is a frequent featured speaker at industry conferences and author of numerous books and articles on industry trends and strategic marketing and management issues. She serves on the advisory board of the Institute for Behavioral Health Informatics.

\section{REFERENCES}

1. Aron, R. and Singh, J.V. "Getting Offshoring Right", Harvard Business Review, December 1, 2005.

2. Babu, M. (2005). "Myth: All Outsourcing Is Offshoring", Computerworld, November 14, 2005. Accessed on March 14, 2007 on www.computerworld at:

http://www.computerworld.com/managementtopics/outsourcing/story/0,10801,105828,00.html?SKC=mana gement-105828

3. Blinder, Alan S. (2005). Fear of Offshoring, Princeton University, Department of Economics, Center for Economic Policy Studies., Working Papers No. 119. Accessed at: http://www.princeton.edu/ ceps/workingpapers/119blinder.pdf

4. Forgione, D. and Smith, P., "Medical Tourism and Its Impact on the US Health Care System", Journal of Health Care Finance, 34(1), Fall (2007):27-35.

5. Garner, Alan C. (2004). Offshoring in the Service Sector: Economic Impact and Policy Issues, Federal Reserve Bank of Kansas City, www.kansascityfed.org. Accessed at http://www.kansascityfed.org/PUBLICAT/ECONREV/Pdf/3Q04garn.pdf on March 15, 2008.

6. Hamilton and Fisher (2006). Center of Excellence: An evolving concept - and controversy. American Academy of Orthopaedic Surgeons Bulletin, February 2006.

http://www2.aaos.org/aaos/archives/bulletin/feb06/fline8.asp, Accessed on March 15, 2008.

7. $\quad$ In 2008, About Half of Large U.S. Employers Offer a CDHP, Up From 39\% in 2007. (2008, April 7). OPEN MINDS On-Line News.

8. Norwood et al (2006) Off-Shoring: An Elusive Phenomenon. National Academy of Public Administration

9. Oss, Monica E. (2007, October). A Forward Look: How New Technologies Are Changing the Field. OPEN MINDS, The Behavioral Health \& Social Service Industry Analyst, 19:7, 2-3, 12.

10. Overby, S (2007). "The ABCs of Outsourcing”, CIO Magazine, June 8,2007. Accessed on March 14, 2008 on cio.com at: http://www.cio.com/article/118100/The_ABCs_of_Outsourcing.

11. Wanless, S., "Meeting the Challenge of Medical Tourism with Healthcare Business Intelligence", accessed March 14, 2008 at: http://www.b-eye-network.com/view/4324. 